\title{
The Influence of The Students' Mastery of Vocabulary on Paraphrasing Ability
}

\author{
Muhammad Muslih \\ Akademi Maritim Cirebon, West Java, Indonesia \\ Email : muslihmunaya@gmail.com
}

Article history: received November 29, 2020; accepted April 21, 2021; published April 23, 2021

\begin{abstract}
Some countries much use English as an international language all over the world. Unfortunately, the use of English in some countries is different from each other. In this case, Indonesia uses English as a foreign language. There are four English skills, listening, speaking, reading, and writing. The mastery of vocabulary is a vital aspect in learning a language; we will not be able to speak to read, and write any language if we do not master it in vocabulary. Therefore, vocabulary has an essential role because it is his primary instrument of language. The student's mastery of English vocabulary is still low. Some factors that cause why the students' vocabulary is still low are the teacher's technique that does not motivate students in learning English. Instrument of the collecting data used by the writer is observation, interview, and test. In doing research, the writer uses a quantitative approach. It means that the data being obtained are presented by number and then interpreted by using statistical analysis. The conclusion of the research is the application of mastery of vocabulary on ability in making paraphrase. It is is know the result the student' of the mastery of vocabulary (X variable) in the average of 71.142 and the result the students' of ability in making paraphrase ( $Y$ variable) in the average of 68.00 . Correlation of $C$ variable on $Y$ variable showing $0.418 \%$. It means that 0.418 is enough to influence the correlation between applying the students' mastery of vocabulary on their ability to make paraphrase.
\end{abstract}

Keywords: English Language, Paraphrasing Ability, Mastery of Vocabulary

\section{Copyright (0) 2021 The Author(s)}

This is an open-access article under the CC BY-SA license.

\section{INTRODUCTION}

Hornby (2000:958) describes that vocabulary as several words that make up language (ASHCROFT, GARNER, and HADINGHAM 2018; Martin 2017). All the words know to a person or used in a particular book, subject, etc. A list of words with their meaning especially accompanies a textbook in a foreign language. The writer assumed that mastery of vocabulary is a vital aspect of learning a language. People will not be able to speak, read, and write any language if they do not master vocabulary. Therefore, vocabulary has an essential role because it is the primary instrument of language. Krisdalaksana (1993:127) defines the vocabulary (lexicon) as follow; 1 ) A language component that makes all information about the meaning and understanding of words in a language, 2) Vocabulary that is possessed by a speaker, a writer or a language, vocabulary, 3) List of words which are arranged like a dictionary, but with brief and practice explanation.

The same explanation is suggested by Groy (1986:24), vocabulary is all of the works possessed in a language. The mastery of vocabulary is vital in learning the language. The learners will not be able to speak, read, and write any language if they do not master vocabulary. 
Muhammad Muslih | The Influence of The Students' Mastery of Vocabulary on Paraphrasing Ability

Therefore, vocabulary has an essential role because it is the primary instrument of language. Hornby (2000:780) stated that mastery is excellent knowledge about or understanding of a particular thing.

Vocabulary mastery is not a spontaneous process. It is a gradual process to aim at stable vocabulary mastery. Mackey (1961:102) stated that as a general rule. Flor Arts and Jan Aart (1998:220) explain that there four major word classes in English. They are nouns, adjectives, adverbs, and verbs. The little words are seven classes: prepositions conjunctions, articles, numerals, pronouns, quantifiers, and interjection (Schulte Im Walde 2020; Sermsook, Liamnimitr, and Pochakorn 2017).

Marcella Frank's theory $(1972: 6)$ has eight types of vocabulary in language teaching (Susanto 2017; Shahbaz and Khan 2017; Azim et al. 2020). These types of vocabulary are called part of speech. Mackey (1962:108) stated that: some factors influence the success and failure of learning English as a foreign language. They are:

Linguistic

Process and progress in second - language learning on (a) how the second language differs from the first and (b) how much the first language interferes with the second Differences

Learning a second language that is highly similar to the first is not the same as learning an entirely different language. The similarities and differences may be in phonology, grammar, vocabulary style, or graphics.

Interferences

The type of interference depends on whether the learner is speaking the language or simply trying to understand what he hears or what he reads.

Social

Since language is essentially a social phenomenon, the social influence its acquisition are numerous and interrelated in complex ways. It is the play of these influences on the growing mind that result in the learning and maintenance of a second language. These may be analyzed as (a) a number of language contacts operated by (b) a number of different factors.

Contact

The groups of the persons with whom we continually use a language have the same effect on the manner and skill with which we use it. So do the situation in which we are placed. These groups or contacts may be enumerated as home and community.

Factor

These contacts may vary according to the following factors: time, population, use, skill, standard attitude, and pressure.

A paraphrase is a restatement of a source in about the same number of words. Paraphrasing enables you to help your audience understanding the result of your reading. Paraphrase when you can (a) clarify poor writing in your source or (b) restate complex material more simply.

Restatement of someone else's words should honor two critical principles, your version should be almost entirely in your words, and your words should accurately convey the content of the original passage. If you simply change a few words in a passage, you have not adequately restated it. Paraphrasing is a writing skill in which you"rephrase" (write) information from an outside source in your own words without changing its meaning because you include your rewriting all, or nearly all, of the content of the original passage, a paraphrase is almost as long. In paraphrasing, however, you must not change the meaning of the original.

When paraphrasing, it is crucial to avoid plagiarizing, writing paraphrase that is too similar to the original. A paraphrase is unacceptable when it contains the same vocabulary and sentence structure as the original. You can write a good paraphrase if you follow these steps: 
Muhammad Muslih | The Influence of The Students' Mastery of Vocabulary on Paraphrasing Ability

\section{Step 1}

Read the original passage several times until you understand it fully. Look up unfamiliar words, and find a synonym for them. If you need to take notes, write down only one or two words for each idea-note a complete sentence. For example, here is one writer's note on the original passage about universal language:

Language people use to communicate but too many abstract dream international language reasons: cultural, economic bonds, good feelings between countries.

It may be helpful to make a brief outline like the following:

Language primary means of communication

Too many language barriers to understanding

Universal language needed

Reasons for the universal language

Increase cultural, economic bonds

Increase good feeling between countries

Step 2

Write your paraphrase from memory. Include as much of the information as you remember, do not look at the original while you are writing.

Step 3

Check paraphrase for accuracy and competence. If necessary, add points you have missed. Step 4

Name the source of the original passage in parentheses at the end of your paraphrase. Paraphrase is a restatement of a text or passage, using other words. The term "paraphrase" drives via the Latin "paraphrases" from the Greek paraphrasing, meaning "additional manner of expression". A paraphrase typically explains or clarifies the text that is being paraphrased. A paraphrase need not accompany a direct quotation, but when this is so, the paraphrase typically serves to put the source's statement into perspective or to clarify the context in which it appeared. A paraphrase is typically more detailed than a summary.

Paraphrase is a parse restatement of the central ideas of a poem in your own language or a restatement in your own words of someone else's ideas or observations. When paraphrasing, it is essential to acknowledge that original source in order to avoid plagiarism. The act of using your own words is to express the idea of another. A restatement giving the meaning in different words is called a paraphrase. We are interested in the two techniques we use to acknowledge the writer whose ideas that paraphrasing. Within the text and outside the text, in brackets. Paraphrase means using your words to express someone else's ideas, and a rough distinction is that paraphrasing refers to editing the text. These two skills (summary and paraphrases) some together in need for abstract vocabulary, where you summarize views for or against a particular situation, phenomenon, feature, or difference: e.g., such differences may be related to ... whether responsibility for communication rests with the reader or writer."

Characteristics of a well-done paraphrase

Is Not Summary

It Does Not Contain Most of The Words or Paraphrase From The Original Plagiarism

It Includes All The Minor Details From Original

The meaning of the writing being paraphrased is more evident to the reader than in the original text.

It Restates The Thesis

It Is Usually Longer Than The Original 
Muhammad Muslih | The Influence of The Students' Mastery of Vocabulary on Paraphrasing Ability

\section{METHOD}

\section{Research Design}

This research aims to determine the influence of the students' mastery of vocabulary on their ability to make paraphrases at the year's students of MTs Subulul Ikhsan Kersana Brebes. The writer uses the quantitative method and formula of statistics, especially the productmoment correlation by the person. The writer takes all students 70 because the subject is less than 100.

In this research, the techniques of collecting data used by the writer are as follows:

This research aims to determine the influence of the student's mastery of vocabulary on their ability to make paraphrases at the year's students of MTs Subulul Ikhsan Kersana Brebes. The writer uses the quantitative method and formula of statistics, especially the formula of productmoment correlation. The writer takes all students 70 because the subject is less than 100 .

In this research, the techniques of collecting data used by the writer are as follows:

\section{Observation}

In this case, the writer has observed the process of teaching and learning English, especially in vocabulary and paraphrase.

\section{Interview}

The writer has interviewed the English teachers about the strategies they use in teaching vocabulary and paraphrase and students' interest in learning English, especially in vocabulary and paraphrase.

Test

To know the student's mastery of vocabulary and their ability to make paraphrase, the writer gives students written reading tests and writing paraphrase. The teacher has presented the test on vocabulary and write paraphrases to the students of class eighth $A$ and $B$.

In analyzing data, the writer uses qualitative and quantitative data. Qualitative data are obtained from analysis on the objective condition of the school, the teacher, students, and facilities that belong to the school. Quantitative data to obtain quantitative data, the writer analyzed the data based on the test result. The data was then analyzed by using the formula of product-moment correlation as follows:

$r_{x y}=\frac{N \Sigma x y-(\Sigma x)(\Sigma y)}{\sqrt{\left[N . \Sigma x^{2}-(\Sigma x)\right][N . \Sigma y-(\Sigma y) 2}}$

$r_{x y}=$ correlation between variable $X$ and $Y$

$X=$ variable $X$ (the students' mastery of vovabulary)

$Y=$ variable $Y$ (the students' ability in making paraphrase)

To determine whether the research has significant influence or not and to know the contribution of $X$ variable to $Y$ variable, the writer uses the formula of DC (determination coefficient as follow:

$D C=r^{2} x 100 \%$

$r=$ correlation coefficient

\section{RESULTS AND DISCUSSION}

\section{The Students' Master of Vocabulary}

The test on the mastery of vocabulary has given to the students for knowing the students' achievement in learning mastery of vocabulary. The test consists of 10 items that are taken from the exercise. The result of the test who are learning mastery of vocabulary can be seen in table 1. 
Muhammad Muslih | The Influence of The Students' Mastery of Vocabulary on Paraphrasing Ability

Table 1. The students' mastery of the vocabulary of class VIII A (X variable)

\begin{tabular}{ccc}
\hline No & Category & Score \\
\hline 1 & Lowest Score & 50 \\
2 & The highest Score & 90 \\
3 & Average & 70.85 \\
\hline
\end{tabular}

Tabel 2. Total Score of Mastery Vocabulary VIII A

\begin{tabular}{cccc}
\hline No & Score & Number of Students & Total Score \\
\hline 1 & 50 & 3 & 250 \\
2 & 60 & 4 & 240 \\
3 & 70 & 9 & 630 \\
4 & 80 & 16 & 1280 \\
5 & 90 & 1 & 90 \\
Total & & $\mathrm{N}=35$ & $\mathrm{x}=2490$ \\
\hline
\end{tabular}

Mean

The total score of the mastery of vocabulary from 35 respondents is 2490 . The mean of that data is as follows:

$M_{x=\frac{X}{N}}$

Explananation

$M_{x=\text { Mean of Variable }}$

$\mathrm{X}=$ variable $\mathrm{x}$ (students' response)

$\sum X=$ Total (amount of $x$ )

$\mathrm{N}=$ Total responden

Based on the formula above, the average score of the students' mastery of vocabulary is:

$M_{x}=\frac{2490}{35}=71.142$

The calculation above indicates that learning the mastery of vocabulary for eight-year students of MTs Subulul Ikhsan Kersana Brebes is satisfied. It is based on the classification of students' achievement in the rational final examination that shows the shoe the Score 71.142. it is categorized "good".

\section{The Students' Ability in Making Paraphrase}

To obtain the students' ability to make paraphrases, the writer has also given the test on the reading to the students. The numbers same, and the materials are different with the students who are mastery of vocabulary. The following table below showed the test result in making paraphrase that the students of class VIII B achieve.

Table 3. The students' ability in making paraphrase of class VIII B (Y variable)

\begin{tabular}{ccc}
\hline No & Category & Score \\
\hline 1 & Lowest Score & 50 \\
2 & The highest Score & 80 \\
3 & Average & 67.15 \\
\hline
\end{tabular}


Muhammad Muslih | The Influence of The Students' Mastery of Vocabulary on Paraphrasing Ability

Tabel 4. The total score of ability in making paraphrase VIII B

\begin{tabular}{cccc}
\hline No & Score & Number of Students & Total Score \\
\hline 1 & 50 & 2 & 100 \\
2 & 60 & 12 & 720 \\
3 & 70 & 15 & 1050 \\
4 & 80 & 6 & 480 \\
Total & & $\mathrm{N}=35$ & $\mathrm{x}=2380$ \\
\hline
\end{tabular}

Mean

The mean score of the data above can be calculated as follow:

$M_{y}=\frac{\Sigma y}{N}$

$M_{y}=$ mean of the variable

$X=$ variable $y$ (student response)

$\Sigma y=$ total (amount of $\mathrm{y}$ )

$\mathrm{N}=$ total respondents

$M_{y}=\frac{2380}{35}=68.00$

Based on the classification of the students' achievement in the national final examination decided by the department of national education, the score 68 is categorized as "sufficient". This indicates that the ability to make paraphrases carried out by the English teacher of NTs Subulul Ikhsan Kersana Brebes is sufficiently achieved.

The Influence of The Students' Mastery of Vocabulary on Their Ability in Making Paraphrase

After knowing the students' mastery of vocabulary as $X$ variable and the students' ability to paraphrase as $Y$ variable, the writer will correlate them. The data are connected through a test. The formulation is as follows:

$r_{x y}=\frac{N \Sigma x y-(\Sigma x)(\Sigma y)}{\sqrt{N \cdot \Sigma x^{2}}-(\Sigma x)^{2} \mid N \cdot \Sigma y-(\Sigma y)^{2}}$

The data of the research variable include variable $x$, variable $y, x^{2}, y^{2}$, and $x y$. The writer has made a table to put them in the table 5 of research variables as follows:

Table 5. The Students' Mastery of vocabulary (X Variable) and students' Ability in making paraphrase ( $\mathrm{Y}$ variable)

\begin{tabular}{ccc}
\hline No & Variable & Total \\
\hline 1 & $\mathrm{x}$ & 5010 \\
2 & $\mathrm{y}$ & 4740 \\
3 & $\mathrm{x}^{2}$ & 36490 \\
4 & $\mathrm{y}^{2}$ & 32600 \\
5 & $\mathrm{xy}$ & 34180 \\
6 & $\mathrm{~N}$ & 70 \\
\hline
\end{tabular}

$$
\begin{aligned}
r_{x y} & =\frac{N \Sigma x y-(\Sigma x)(\Sigma y)}{\sqrt{\left[N . \Sigma x^{2}-(\Sigma x)^{2}\right\rceil\left[N . \Sigma y-(\Sigma v)^{2}\right\rceil}} \\
& =\frac{70.34180-(5010)(4740)}{\sqrt{\left[70.36490-(5010)^{2}\right]\left[70.32600-(4740)^{2}\right\rceil}} \\
& =\frac{2392600-2374740}{\sqrt{\left[2554300-(2510010)^{2}\right][228200-2246760]}} \\
& =\frac{17860}{\sqrt{[44290][35240]}} \\
& =\frac{17860}{\sqrt{156077960}}
\end{aligned}
$$


Muhammad Muslih | The Influence of The Students' Mastery of Vocabulary on Paraphrasing Ability

$$
\begin{aligned}
& =\frac{17860}{3950.6700} \\
& =0.425
\end{aligned}
$$

Based on the result of the correlation above. It is obtained that the score show 0.452 referring to the table of interpretation, the score of 0.452 is enough; it is from 0.40 to 0.60 . Therefore, there is a positive and significant influence of the students' mastery of vocabulary on their ability in making paraphrase.

Here the correlation between $\mathrm{x}$ and $\mathrm{y}$ variables based on the formula of determination confidence:

$$
\begin{aligned}
\text { DC } & =r^{2} \times 100 \% \\
& =0.452^{2} \times 100 \% \\
& =0.2043 \times 100 \% \\
& =20.43 \%
\end{aligned}
$$

From the calculation coefficient above, it is obtained that score shows $20.43 \%$. therefore, it can be concluded that the $20.43 \%$ y variable (the students' ability in making paraphrase) is influenced by $x$ variable (the students' mastery of vocabulary).

\section{CONCLUSION}

The conclusion of the research is the application of mastery of vocabulary on ability in making paraphrase. It is known from the result the student's mastery of vocabulary (X variable) in the average of 71.142 and the result the students' ability to make paraphrase ( $Y$ variable) in the average of 68.00 . The correlation of $C$ variable on $Y$ variable showing $0.418 \%$. it means that 0.418 is enough to influence level from the correlation between the application of the students' mastery of vocabulary on their ability in making paraphrase.

\section{REFERENCES}

Aarts, Flor and Aarts, Jan. 1998. English Syntactic Structure. Prentice-Hall International (UK)

Al Khuli, M. 1976. English As Foreign Language: Linguistic Background Teaching Method. Riyadh University

Arikunto Suharsimi. 2006. Prosedur Penelitian Suatu Pendekatan Praktek. Jakarta: PT Rieneka Cipta

Echols, Jhon. M and Hasan Shadily. 1975. An English-Indonesia Dictionary. Jakarta: PT. Gramedia

Frank Marcella. 1972. Modern English Practice. Hall New York

Gorys Kraf. 19986. Komposisi Sebuah Kemahiran Bahasa. Jakarta: Nusa Indah

Hornby, As.2000. Oxford Advanced Learner's Dictionary of current Englisg. Oxford University. London

Jamen Mc Crimmon. 1984. Writing With a Purpose. USA. Houghton Miffilin Company

Jhon C. Hodges and Suzane Strobeck Web. 1994. Harbrace College Handbook. Harcourt Press

Kridalaksana. 1993. Linguistic Suatu Pengantar. Bandung: Angkasa

Learning Vocabulary in Another Language. I.SP National Victoria University Press.2001

Margon, S. 1997. Penelitian Pendidikan. Jakarta: Rieneka Cipta

Sudjono, Ana. 2001. Pengantar Statistik Pendidikan. Jakarta. CV. Raja Grapindo

http://www.Lansing.Cc.mi.us 
Muhammad Muslih | The Influence of The Students' Mastery of Vocabulary on Paraphrasing Ability

ASHCROFT, ROBERT JOHN, JOSEPH GARNER, and OLIVER HADINGHAM. 2018. "Incidental Vocabulary Learning Through Watching Movies." Australian Journal of Applied Linguistics 1 (3): 135-47.

Azim, Muhammad Umer, Zaheer Hussain, Azhar Munir Bhatti, and Dr. Muhammad Iqbal. 2020. "Recycling of Vocabulary in English Language Teaching: From Recycling of Vocabulary in English Language Teaching : From Theory To Practice." Epistemology Journal 7 (October): 88-102.

Martin, Fermin Moscoso del Prado. 2017. "Vocabulary, Grammar, Sex, and Aging." COGNITIVE SCIENCE A MULTIDISCIPLINARY JOURNAL 41: 950-75. https://doi.org/10.1111/cogs.12367.

Schulte Im Walde, Sabine. 2020. "Distinguishing between Paradigmatic Semantic Relations across Word Classes: Human Ratings and Distributional Similarity." Journal of Language Modelling 8 (1): 53-101. https://doi.org/10.15398/JLM.V8I1.199.

Sermsook, Kanyakorn, Jiraporn Liamnimitr, and Rattaneekorn Pochakorn. 2017. "An Analysis of Errors in Written English Sentences: A Case Study of Thai EFL Students." English Language Teaching 10 (3): 101. https://doi.org/10.5539/elt.v10n3p101.

Shahbaz, Muhammad, and Raja Muhammad Ishtiaq Khan. 2017. "Use of Mobile Immersion in Foreign Language Teaching to Enhance Target Language Vocabulary Learning." MIER Journal of Educational Studies, Trends and Practices 7 (1): 66-82.

Susanto, Alpino. 2017. "THE TEACHING OF VOCABULARY: A PERSPECTIVE." Jurnal KATA 1 (2): 182. https://doi.org/10.22216/jk.v1i2.2136. 